\title{
Comparative Study of Propofol and Etomidate on the Haemodynamic Effects During Induction and Endotracheal Intubation
}

\author{
Mallika Rayamajhi', Puja Thapa', Anjan Khadka ${ }^{2}$, Biswa Ram Amatya' ${ }^{1}$ and Udaya Bajracharya ${ }^{1}$
}

${ }^{1}$ Department of Anaesthesiology, Nepalese Army Institute of Health Sciences, Shree Birendra Hospital, Chhauni, Kathmandu, Nepal

${ }^{2}$ Department of Pharmacology, Nepalese Army Institute of Health Sciences, Shree Birendra Hospital, Chhauni, Kathmandu, Nepal

\begin{abstract}
Introduction: While most intravenous induction agents decrease arterial blood pressure, laryngoscopy and endotracheal intubation increase the heart rate and blood pressure. Propofol causes a decrease in systemic blood pressure whereas etomidate has minimal effects on the cardiovascular system. This study aims to evaluate and compare the hemodynamic effects of propofol and etomidate during induction and endotracheal intubation.

Methods: 62 ASA I and II patients, 20-60 years of age, scheduled for elective surgery were enrolled in this prospective, randomised and double blind comparative study. Group A received inj. Propofol (2 mg/kg) and group $\mathrm{B}$ received inj. Etomidate $(0.3 \mathrm{mg} / \mathrm{kg})$, as induction agents. Heart rate, systolic blood pressure, diastolic blood pressure and mean arterial blood pressure were recorded after induction and after intubation at one, three, five and ten minutes and intergroup comparisons were made.

Results: After induction the decrease in systolic, diastolic and the mean arterial pressures were more in group A compared to group B ( $p=0.003,0.004$ and 0.002$)$. After 1 minute of intubation all haemodynamic parameters increased from the baseline with no significant differences between the two groups $(p>0.05)$. At three minutes the decrease in heart rate, diastolic blood pressure and mean arterial pressure was more in group A than group B with $\mathrm{p}$ values of $0.001,0.002$ and 0.05 , however systolic blood pressures showed no significant difference $(p=0.144)$. The decrease in blood pressures showed significant difference between the two groups $(p<0.05)$ at five and ten minutes but the decrease in heart rate remained significant only at five minutes of intubation $(p=0.001)$.

Conclusions: Propofol and etomidate are both effective in preventing the haemodynamic changes due to induction and endotracheal intubation, with etomidate providing more haemodynamic stability.
\end{abstract}

Key words: etomidate; haemodynamics; induction; intubation; propofol

Correspondence: Mallika Rayamajhi, Department of Anaesthesiology, Nepalese Army Institute of Health Sciences, Shree Birendra Hospital, Chhauni, Kathmandu, Nepal. E-mail: mallika_rayamajhi@hotmail.com.

DOI: http://dx.doi.org/10.3126/mjsbh.v18i2.20907

Submitted on: 2018-08-29

Accepted on: 2018-11-12

This work is licensed under creative common license:

http://creativecommons.org/licenses/by-nc-nd/4.0/ C MJSBH 2019 


\section{INTRODUCTION}

The increasing importance of safe anaesthesia practice has accentuated the need for anaesthetic techniques with smooth induction and intubation, stable intra-operative haemodynamic and rapid recovery with minimal adverse effects.

Anaesthetic induction agents may decrease arterial blood pressure via myocardial depression, vasodilatation and attenuation of autonomic nervous activity. ${ }^{1-4}$ Conversely, laryngoscopy and endotracheal intubation induces a sympathetic response resulting in a rise in heart rate and blood pressure. $^{5-8}$ These fluctuations in heart rate and blood pressure though brief and well tolerated by healthy individuals, may be deleterious in patients with cardiovascular compromise. The choice of induction agent hence should be able to maintain a safe range of haemodynamic parameters i.e. heart rate, systolic blood pressure, diastolic blood pressure and the mean arterial pressure.

Propofol causes a decrease in systemic blood pressure accompanied by changes in cardiac output and systemic vascular resistance. ${ }^{9}$ Etomidate with its minimal effects on the cardiovascular system causes mild reduction in peripheral vascular resistance with a slight decline in arterial blood pressure but myocardial contractility and cardiac output are unchanged. ${ }^{10}$

This study aims to evaluate the effects of propofol and etomidate during induction and intubation by comparing the heart rate, systolic and diastolic blood pressure and the mean arterial pressure, so that we can choose a safer drug as per its pharmacodynamics and the clinical presentation of the patient.

\section{METHODS}

This is a prospective, randomised and double blind comparative study conducted in a tertiary level hospital of Nepal. After approval from the Institutional Review Board of the hospital, 62 cases were taken as sample and divided into two groups ' $\mathrm{A}$ ' and ' $\mathrm{B}$ ', consisting of 31 patients in each group. Group A received inj. propofol $(2 \mathrm{mg} /$ $\mathrm{kg})$ and group B received inj. etomidate $(0.3 \mathrm{mg} /$ $\mathrm{kg}$ ), as induction agents. The patients enrolled were of both genders, aged between 20 to 60 years, American Society of Anaesthesiologist Physical Status (ASA) I and II, scheduled for elective surgery requiring general anaesthesia with endotracheal intubation. Patients with known allergy to propofol or etomidate, sinus bradycardia, history of bronchospasm, seizure disorder, arrhythmias and ischaemic heart disease were excluded from the study.

Pre-anaesthetic check-up was done a day before surgery and informed written consent was obtained. Patients were pre medicated with diazepam $5 \mathrm{mg}$ and kept nil per oral after midnight. Patients were randomly allocated into two groups by lottery method.

Inside the operation theatre baseline value of systolic blood pressure, diastolic blood pressure, mean arterial pressure, heart rate and $\mathrm{SPO}_{2}$ were recorded. Patients were pre medicated with injection midazolam $0.04 \mathrm{mg} / \mathrm{kg}$ and injection Fentanyl $2 \mu \mathrm{g} / \mathrm{kg}$ was given for analgesia. Preoxygenation was done with $100 \%$ Oxygen for three minutes. The anaesthetic assistant prepared the drug as per the group mentioned in the lottery slip without showing it to us. Then anesthesias was induced with the study drug (Propofol $2 \mathrm{mg} / \mathrm{kg}$ or Etomidate $0.3 \mathrm{mg} / \mathrm{kg}$ ) as per group over 20 seconds by the anaesthetic assistant five minutes prior to laryngoscopy and intubation. The heart rate, systolic blood pressure, diastolic blood pressure and mean arterial pressure were again noted. Muscle relaxation was achieved by administering vecuronium. Three minutes after administering vecuronium, laryngoscopy was performed using a standard Macintosh laryngoscope blade and trachea was intubated with proper size cuffed tube and fixed after confirmation of correct position.

Haemodynamic variables i.e. heart rate, systolic blood pressure, diastolic blood pressure and mean arterial blood pressure were recorded immediately after one minute of intubation and then after thee, five and 10 minutes. During those 10 minutes all surgical stimulations were avoided. After that heart 
rate and blood pressure were recorded every 15 minutes till the end of surgery.

Data were analysed using Statistical software, SPSS. Categorical variables like gender and ASA were compared by using chi square test. Independent t-test was used for comparison between two groups for continuous variables like heart rate, systolic blood pressure, diastolic blood pressure and mean arterial pressure. Paired t test was used for comparison of heart rate, systolic blood pressure, diastolic blood pressure and mean arterial pressure within a group at different time intervals and $\mathrm{p}$ value was calculated. $\mathrm{P}$ value less than 0.05 was taken statistically significant. Results were presented as mean $\pm \mathrm{SD}$.

\section{RESULTS}

A total of 62 patients were included in this study. The groups were comparable in terms of age, weight and ASA status. However unintentionally this study had more female population included (Table 1).

This study observed the changes in heart rate, systolic blood pressure, diastolic blood pressure and mean arterial blood pressure after drug administration and the first 10 minutes after laryngoscopy and intubation and compared them between the two groups. There was no statistically significant difference in the baseline haemodynamic variables (heart rate, systolic blood pressure, diastolic blood pressure and mean arterial blood pressure) between the two groups (Table 2).

After drug administration both the groups showed a decrease in the haemodynamic variables with statistically significant difference between the two groups in terms of the systolic $(p=0.003)$ and

Table 1. Demographic Data of Patient

\begin{tabular}{|l|l|l|}
\hline Variables & Group A & Group B \\
\hline Age ( years) & $37.67 \pm 11.542$ & $38.48 \pm 13.463$ \\
\hline Gender (M/F) & $7 / 24$ & $5 / 26$ \\
\hline Weight (kg) & $54.30 \pm 13.364$ & $56.88 \pm 11.084$ \\
\hline ASA (I/II) & $30 / 1$ & $26 / 5$ \\
\hline
\end{tabular}

Table 2. Baseline (Pre-induction) Haemodynamic Variables (Mean \pm SD)

\begin{tabular}{|c|c|c|c|}
\hline Variables & Group A & Group B & $\begin{array}{l}P \\
\text { value }\end{array}$ \\
\hline Baseline heart rate & $\begin{array}{l}85.8064 \pm \\
14.9920\end{array}$ & $\begin{array}{l}84.7096 \pm \\
12.7989\end{array}$ & 0.378 \\
\hline $\begin{array}{l}\text { Baseline systolic } \\
\text { blood pressure }\end{array}$ & $\begin{array}{l}127.54 \pm \\
17.682\end{array}$ & $\begin{array}{l}132.32 \pm \\
20.007\end{array}$ & 0.161 \\
\hline $\begin{array}{l}\text { Baseline diastolic } \\
\text { blood pressure }\end{array}$ & $\begin{array}{l}77.90 \pm \\
12.329\end{array}$ & $\begin{array}{l}82.03 \pm \\
9.648\end{array}$ & 0.073 \\
\hline $\begin{array}{l}\text { Baseline mean } \\
\text { arterial pressure }\end{array}$ & $\begin{array}{l}94.19 \pm \\
12.676\end{array}$ & $\begin{array}{l}98.48 \pm \\
11.433\end{array}$ & 0.083 \\
\hline
\end{tabular}

diastolic $(\mathrm{p}=0.004)$ blood pressure and the mean arterial pressure $(p=0.002)$ but the changes in heart rate between the two groups was not significant $(\mathrm{p}=0.416)$ as shown in tables $3,4,5$ and 6 respectively.

After one minute of laryngoscopy and intubation all variables increased from the baseline but there were no statistically significant differences between the two groups $(p>0.05)$. However after three minutes of intubation all parameters decreased from the baseline and the difference in heart rate, diastolic blood pressure and mean arterial pressure were statistically significant with $\mathrm{p}$ values of 0.001 ,

Table 3. Comparison of heart rate change between two groups $($ Mean $\pm \mathrm{SD})$

\begin{tabular}{|l|l|l|l|}
\hline Heart Rate & Group A & Group B & P value \\
\hline Baseline & $\begin{array}{l}85.8064 \pm \\
14.9920\end{array}$ & $\begin{array}{l}84.7096 \pm \\
12.7989\end{array}$ & 0.378 \\
\hline $\begin{array}{l}\text { After } \\
\text { administration } \\
\text { of drug }\end{array}$ & $\begin{array}{l}84.2580 \pm \\
17.8287\end{array}$ & $\begin{array}{l}83.4516 \pm \\
11.3720\end{array}$ & 0.416 \\
\hline $\begin{array}{l}\text { After 1 minute } \\
\text { of intubation }\end{array}$ & $\begin{array}{l}91.8387 \pm \\
15.7249\end{array}$ & $\begin{array}{l}90.8387 \pm \\
12.5142\end{array}$ & 0.391 \\
\hline $\begin{array}{l}\text { After 3 } \\
\text { minutes of } \\
\text { intubation }\end{array}$ & $\begin{array}{l}77.4838 \pm \\
9.8111\end{array}$ & $\begin{array}{l}86.1290 \pm \\
12.5505\end{array}$ & 0.001 \\
\hline $\begin{array}{l}\text { After 5 } \\
\text { minutes of } \\
\text { intubation }\end{array}$ & $\begin{array}{l}72.6129 \pm \\
9.4116\end{array}$ & $\begin{array}{l}81.2903 \pm \\
12.3833\end{array}$ & 0.001 \\
\hline $\begin{array}{l}\text { After 10 } \\
\text { minutes of } \\
\text { intubation }\end{array}$ & $\begin{array}{l}77.0967 \pm \\
26.5961\end{array}$ & $\begin{array}{l}79.4193 \pm \\
12.8757\end{array}$ & 0.331 \\
\hline
\end{tabular}




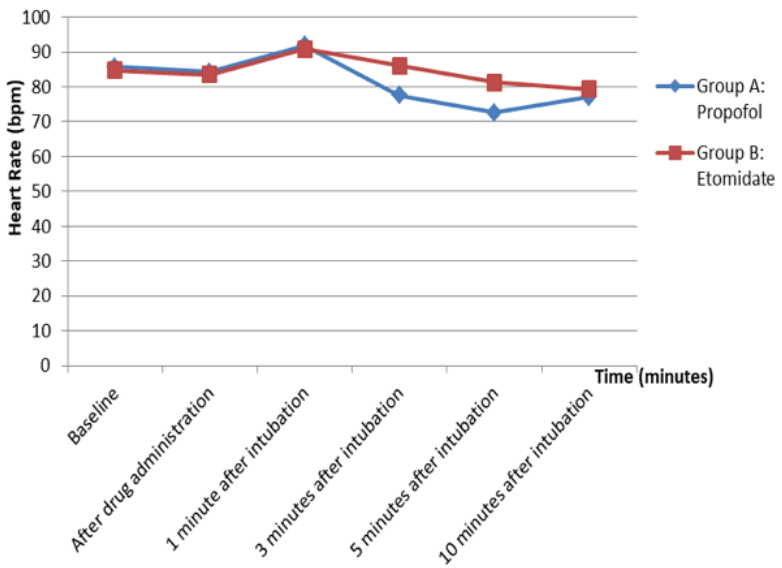

Figure 1. Heart Rate in two groups at different time intervals

0.002 and 0.05 respectively but systolic blood pressures showed no significant difference between the two groups $(p=0.144)$. Similarly at 5 and 10 minutes of intubation the systolic blood pressure, diastolic blood pressure and the mean arterial pressure remained lower than that of the baseline in both the groups with statistically significant difference between them $(\mathrm{p}<0.05)$. Heart rate, though decreased from baseline in both the groups, the difference between them remained statistically significant only at 5 minutes of intubation $(\mathrm{p}=$ 0.001 ) as shown in tables 3, 4, 5, 6 and figures 1, 2, 3,4 .

\section{DISCUSSION}

Induction of general anaesthesia can be achieved by various inhalational and intravenous agents. The

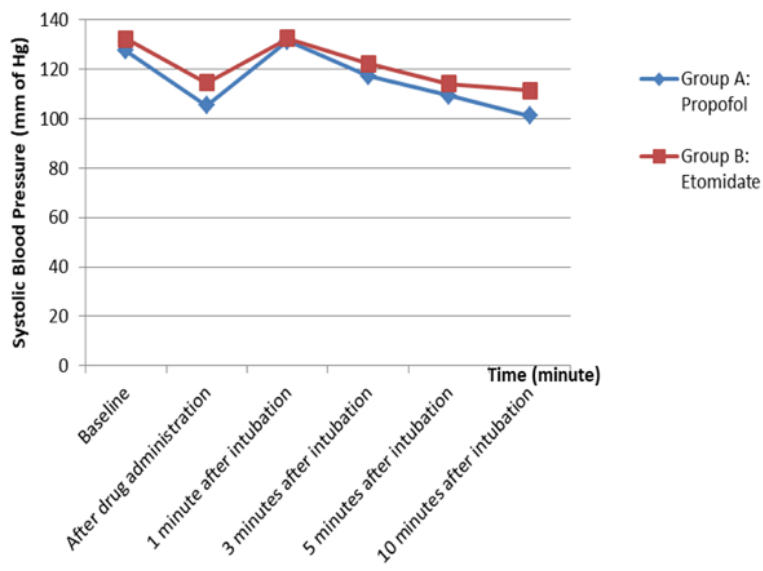

Figure 2. Systolic Blood Pressure in two groups at different time intervals
Table 4. Comparison of Systolic Blood Pressure change between two groups (Mean $\pm \mathrm{SD}$ )

\begin{tabular}{|c|c|c|c|}
\hline $\begin{array}{l}\text { Systolic blood } \\
\text { pressure }\end{array}$ & Group A & Group B & $\underset{\text { value }}{\mathbf{p}}$ \\
\hline Baseline & $\begin{array}{l}127.54 \pm \\
17.682\end{array}$ & $\begin{array}{l}132.32 \pm \\
20.007\end{array}$ & 0.161 \\
\hline $\begin{array}{l}\text { After } \\
\text { administration } \\
\text { of drug }\end{array}$ & $\begin{array}{l}105.45 \pm \\
13.428\end{array}$ & $\begin{array}{l}114.45 \pm \\
11.534\end{array}$ & 0.003 \\
\hline $\begin{array}{l}\text { After } 1 \text { minute } \\
\text { of intubation }\end{array}$ & $\begin{array}{l}131.41 \pm \\
23.563\end{array}$ & $\begin{array}{l}132.48 \pm \\
14.030\end{array}$ & 0.414 \\
\hline $\begin{array}{l}\text { After } 3 \text { minutes } \\
\text { of intubation }\end{array}$ & $\begin{array}{l}117.32 \pm \\
19.715\end{array}$ & $\begin{array}{l}122.19 \pm \\
15.994\end{array}$ & 0.144 \\
\hline $\begin{array}{l}\text { After } 5 \text { minutes } \\
\text { of intubation }\end{array}$ & $\begin{array}{l}109.22 \pm \\
15.966\end{array}$ & $\begin{array}{l}114.22 \pm \\
11.786\end{array}$ & 0.083 \\
\hline $\begin{array}{l}\text { After } 10 \\
\text { minutes of } \\
\text { intubation }\end{array}$ & $\begin{array}{l}101.22 \pm \\
12.576\end{array}$ & $\begin{array}{l}111.45 \pm \\
14.527\end{array}$ & 0.002 \\
\hline
\end{tabular}

choice of induction agent in any individual patient is determined by co-existent cardiovascular, intracranial or reactive airway diseases, hypertension or hypotension or hypovolemia, as well as the individual physician's personal preference of agent. ${ }^{11}$ Propofol and etomidate are well known for their anaesthesia induction properties. Independent of the presence of cardiovascular disease, propofol causes a decrease in blood pressure (systolic blood pressure, diastolic

Table 5. Comparison of Diastolic Blood Pressure change between two groups (Mean \pm SD)

\begin{tabular}{|l|l|l|l|}
\hline $\begin{array}{l}\text { Diastolic Blood } \\
\text { Pressure }\end{array}$ & Group A & Group B & $\begin{array}{l}\text { P } \\
\text { value }\end{array}$ \\
\hline Baseline & $\begin{array}{l}77.90 \pm \\
12.329\end{array}$ & $\begin{array}{l}82.03 \pm \\
9.648\end{array}$ & 0.073 \\
\hline $\begin{array}{l}\text { After } \\
\text { administration of } \\
\text { drug }\end{array}$ & $\begin{array}{l}67.09 \pm \\
12.506\end{array}$ & $\begin{array}{l}75.03 \pm \\
10.805\end{array}$ & 0.004 \\
\hline $\begin{array}{l}\text { After 1 minute of } \\
\text { intubation }\end{array}$ & $\begin{array}{l}85.93 \pm \\
17.849\end{array}$ & $\begin{array}{l}89.74 \pm \\
11.117\end{array}$ & 0.159 \\
\hline $\begin{array}{l}\text { After 3 minutes of } \\
\text { intubation }\end{array}$ & $\begin{array}{l}75.25 \pm \\
16.776\end{array}$ & $82.12 \pm$ \\
\hline $\begin{array}{l}\text { After 5 minutes of } \\
\text { intubation }\end{array}$ & $\begin{array}{l}70.41 \pm \\
13.608\end{array}$ & $77.90 \pm$ \\
\hline $\begin{array}{l}\text { After 10 minutes } \\
\text { of intubation }\end{array}$ & $\begin{array}{l}62.93 \pm \\
13.554\end{array}$ & $77 \pm 15.073$ & 0.029 \\
\hline
\end{tabular}




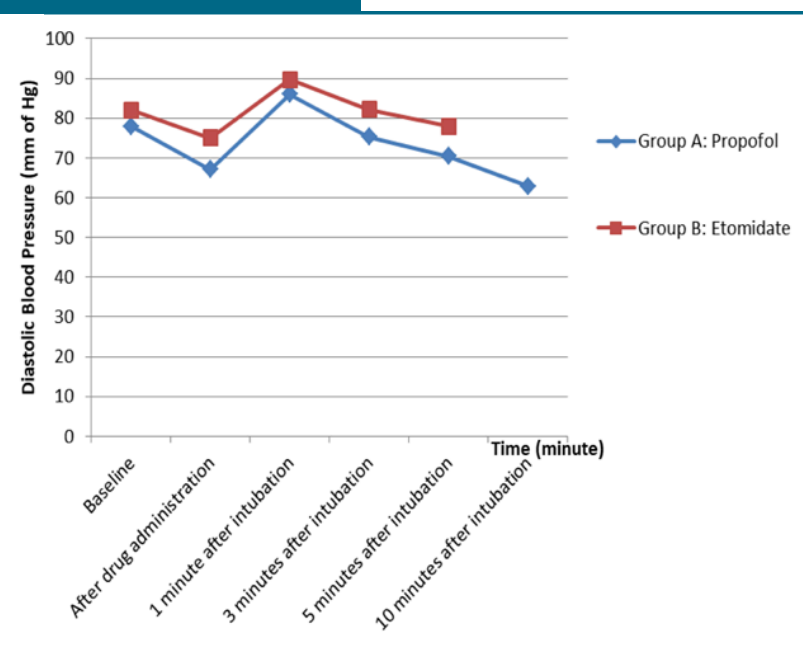

Figure 3. Diastolic Blood Pressure in two groups at different time intervals

blood pressure and mean arterial pressure) but does not significantly change the heart rate during induction of anaesthesia. ${ }^{1}$ Propofol induced hypotension is due to both vasodilatation with reduced preload and afterload and negative inotropic action. ${ }^{1-4}$ The haemodynamic stability seen with etomidate may be due to its unique lack of effect on both the sympathetic nervous system and baroreceptor function ${ }^{1,12,13}$ and its capacity to bind and stimulate peripheral alpha-2B adrenergic receptors with subsequent vasoconstriction. ${ }^{14}$

The haemodynamic variables after induction and for the first 10 minutes after intubation were

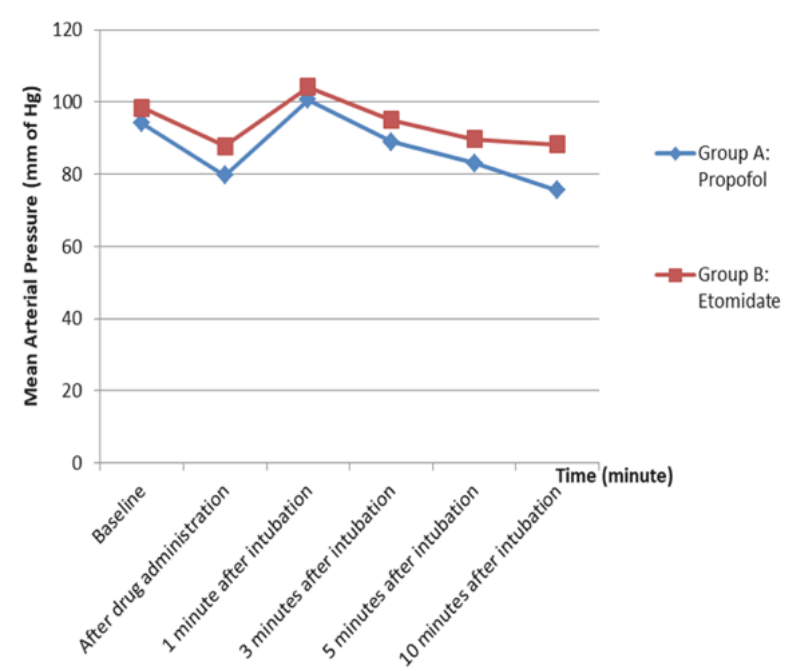

Figure 4. Mean Arterial Pressure in two groups at different time intervals
Table 6. Comparison of Mean Arterial Pressure change between two groups (Mean \pm SD)

\begin{tabular}{|l|l|l|l|}
\hline $\begin{array}{l}\text { Mean Arterial } \\
\text { Pressure }\end{array}$ & Group A & Group B & $\begin{array}{l}\text { P } \\
\text { value }\end{array}$ \\
\hline Baseline & $\begin{array}{l}94.19 \pm \\
12.676\end{array}$ & $\begin{array}{l}98.48 \pm \\
11.433\end{array}$ & 0.083 \\
\hline $\begin{array}{l}\text { After } \\
\text { administration of } \\
\text { drug }\end{array}$ & $\begin{array}{l}79.64 \pm \\
12.177\end{array}$ & $\begin{array}{l}87.83 \pm \\
10.224\end{array}$ & 0.002 \\
\hline $\begin{array}{l}\text { After 1 minute } \\
\text { of intubation }\end{array}$ & $\begin{array}{l}100.61 \pm \\
19.041\end{array}$ & $\begin{array}{l}104.12 \pm \\
11.035\end{array}$ & 0.189 \\
\hline $\begin{array}{l}\text { After 3 minutes } \\
\text { of intubation }\end{array}$ & $\begin{array}{l}89 \pm \\
17.021\end{array}$ & $95 \pm 10.770$ & 0.051 \\
\hline $\begin{array}{l}\text { After 5 minutes } \\
\text { of intubation }\end{array}$ & $\begin{array}{l}83.09 \pm \\
13.825\end{array}$ & $\begin{array}{l}89.70 \pm \\
10.351\end{array}$ & 0.018 \\
\hline $\begin{array}{l}\text { After 10 minutes } \\
\text { of intubation }\end{array}$ & $\begin{array}{l}75.48 \pm \\
12.981\end{array}$ & $\begin{array}{l}88.22 \pm \\
14.587\end{array}$ & 0.000 \\
\hline
\end{tabular}

compared between propofol and etomidate. Our result showed that there is a decrease in heart rate after drug administration in both the groups but the inter group comparison shows no significant difference. The fall in heart rate after drug administration could be attributed to the anxiolytic action of midazolam and fentanyl used for premedication. ${ }^{15}$ The systolic blood pressure, diastolic blood pressure and the mean arterial pressure all decreased after the administration of drug and the hypotensive effect of propofol is significantly more than that of etomidate.

As expected all haemodynamic parameters increased after one minute of laryngoscopy and intubation. Thereafter at intervals of three, five and ten minutes of laryngoscopy and intubation, the decrease in heart rate, systolic blood pressure, diastolic blood pressure and the mean arterial pressure from baseline was greater with propofol than with etomidate. The inter group comparison was significant for heart rate at three and five minutes, systolic blood pressure at 10 minutes only, diastolic blood pressure throughout the 10 minutes interval and the mean arterial pressure only at five minutes interval.

Laryngoscopy and endotracheal intubation induces a sympathetic response resulting in a rise of intracranial pressure, heart rate, blood pressure and 
serum catecholamine..$^{5-8}$ This explains the rise in haemodynamic parameters at one minute after intubation. Thereafter as per the pharmacodynamics of the drugs used we have seen a decrease in haemodynamic variables with etomidate showing better hemodynamic stability. We are however aware that the use of fentanyl as an analgesic in both the groups could have had a synergistic haemodynamic depressant effect. Fentanyl is known to blunt the haemodynamic response to laryngoscopy and tracheal intubation and decrease the incidence of myoclonus associated with etomidate. ${ }^{1,2,14}$

There are various studies which have compared the haemodynamic variations with propofol and etomidate following induction and endotracheal intubation. Similar to our finding, Meena $\mathrm{K}$ et al. ${ }^{16}$ showed that heart rate decreased after induction but increased after laryngoscopy and intubation and the increase with the etomidate group was statistically significantly higher than that of propofol. Their study also showed a significant decrease in arterial blood pressure after induction with propofol which did not increase above baseline value after intubation while with etomidate, there was a significant increase in arterial pressure following intubation, hence showing better haemodynamic condition with etomidate as compared to propofol.

Shah SB et al ${ }^{15}$ in their study showed that propofol caused sustained increase in heart rate throughout induction and intubation while etomidate kept the heart rate stable for the complete duration of induction and intubation and the magnitude of variation in systolic blood pressure, diastolic blood pressure and mean arterial pressure from baseline was greater with propofol. Aggarwal S et al. ${ }^{17}$ observed that propofol caused significant hypotension and tachycardia at induction and intubation in comparison to etomidate. Pandey AK et al. ${ }^{18}$ and Masoudifar et al. ${ }^{19}$ also showed that etomidate provides more stable haemodynamic parameters when used for induction of anaesthesia hence it could be preferred over propofol for general anesthesia.
On the contrary, Ko YK et al. ${ }^{20}$ and Ye L et al. ${ }^{21}$ showed no group differences in systolic blood pressure, diastolic blood pressure and heart rate following intravenous anaesthetic injection and intubation with propofol or etomidate but systolic blood pressure and diastolic blood pressure were substantially higher with etomidate. Moller Petrun et al. ${ }^{22}$ in their study, also found no significant difference between propofol and etomidate in hemodynamic before intubation but the differences between the groups appeared during intubation showing etomidate was less effective in minimising hypertension and tachycardia. Bendel $S$ et al. ${ }^{23}$ found no change in heart rate during the induction in both groups with no differences between the groups.

The main finding of our study was that both propofol and etomidate reduced the rise in heart rate and arterial blood pressure during laryngoscopy and intubation with etomidate showing lesser hypotensive effect. But our study was done in routine surgical cases with younger age group i.e., age less than 60 years and in ASA I and II patients. The changes with heart rate and cardiac output with propofol is usually transient and insignificant in healthy patients but may be severe enough to lead to asystole, particularly in critically ill and in patients at extremes of age. ${ }^{10}$ Probably etomidate could be advocated as the drug of choice for rapid sequence induction in haemodynamically unstable and critically ill patients due to its rapid onset of anaesthesia and minimal effect on the cardiovascular system. ${ }^{11,24-27}$ However several literatures overrides these findings. Glasser $\mathrm{N}$ et al. ${ }^{28}$ in their study showed that though there was an increased rate of hypotension with propofol, it was safer and more effective compared to etomidate as an induction agent for Rapid Sequence Induction (RSI) due to higher mortality rate with etomidate. Skinner HJ et $\mathrm{al}^{26}$ also stated that etomidate could not be recommended for rapid sequence intubation due to a greater presser response following induction with etomidate compared to propofol.

Therefore adequate hydration and a titrated dose of propofol to minimise its hypotensive effect may be 
a reasonable alternative to etomidate since the side effects of propofol are also less. ${ }^{3,9,18}$ Though we have not included the side effects of individual drugs in our study, we are aware of the adrenocortical suppression and the increase incidence of myoclonus associated with etomidate, hence making it a less favourable drug during induction. ${ }^{9,21,24,29}$ Moreover propofol being readily available in our country, still remains the drug of choice for induction and intubation. .

\section{CONCLUSIONS}

This study indicates that propofol and etomidate both decrease the heart rate, systolic and diastolic blood pressures and the mean arterial pressure during induction and are both effective in preventing the haemodynamic changes due to laryngoscopy and intubation, with etomidate providing more cardiovascular stability. However further studies needs to be done to establish the superiority of any one drug over the other by taking into consideration their adverse effects and also the age group, clinical condition and the overall outcome of patients.

\section{LIMITATIONS}

There are several limitations in this study. The study age group ranged between 20 to 60 years, so we could not assess the effects of the drugs at extremes of ages. Only ASA I or II elective surgical cases were selected in this study and therefore we could not assess the effect of the drugs on high risk haemodynamically compromised, critically ill and emergency patients. Moreover we did not randomise our study according to gender and this resulted in over-representation of females. Comparisons were made only between propofol and etomidate but if we had had a control group in our study then we could have appreciated the magnitude of difference between the drug and control group which could have provided better analysis.

To cite this article: Rayamajhi M, Thapa P, Khadka A, Amatya BR, Bajracharya U. Comparative study of Propofol and Etomidate on the hemodynamic effects during induction and endotracheal intubation. MJSBH. 2019;18(2):7-15

Conflict of Interest: None declared

\section{REFERENCES}

1. Miller RD, Reves JG, Glass PS, Lubarsky DA, McEvoy MD. Intravenous non opioid anaesthetics. In: Miller's Anaesthesia; 6th ed. Philadelphia: Elsevier; 2009. p.318-61.

2. Saricaoglu F, Uzun S, Arun O, Arun F, Aypar U. A clinical comparison of etomidate-lipuro, propofol and admixture at induction. Saudi J Anaesth. 2011;5(1):62-6. DOI: https://doi.org/10.4103/1658-354X.76509

3. Weisenberg M, Sessler DI, Tavdi M, Gleb M, Ezri T, Dalton JE. Dose-dependent haemodynamic effects of propofol induction following brotizolam premedication in hypertensive patients taking angiotensin-converting enzyme inhibitors. J Clin Anesth. 2010;22(3):190-5.

DOI: https://doi.org/10.1016/j.jclinane.2009.07.008

4. Larsen JR, Torp P, Norrild K, Sloth E. Propofol reduces tissue-Doppler markers of left ventricle function: A transthoracic echocardiographic study. Br J Anaesth. 2007;98(2):183-8.

DOI: https://doi.org/10.1093/bja/ael345

5. Reid LC, Brace DE. Irritation of the respiratory tract and its reflex effect upon the heart. Surg Gynecol Obstet. 1940;70:157-62.

6. King BD, Harris LC, Greifenstein FE. Reflex circulatory responses to direct laryngoscopy and tracheal intubation performed during general anesthesia. Anesthesiology. 1951;12(\%):556-66.

PMID: 14868891 
7. Forbes AM, Dally F. Acute hypertension during induction of anaesthesia and endotracheal intubation in normotensive men. Br J Anaesth. 1970;42(7):618-24.

DOI: https://doi.org/10.1093/bja/42.7.618

8. Shribman AJ, Smith G, Achola J. Cardiovascular and catecholamine responses to laryngoscopy with and without tracheal intubation. Br J Anaesth. 1987;59(3):295-9.

DOI: https://doi.org/10.1093/bja/59.3.295

9. Stoelting RK, Hillier SC. Non barbiturates Intravenous Anaesthetic Drugs. Handbook of Pharmacology and Physiology in Anaesthetic Practice; 4th ed. 2006;152-166.

10. Morgan GE, Mikhail MS, Murray MJ. Non Volatile Anaesthetic Agents. In: Clinical Anaesthesiology. 4th ed. McGraw-Hill Medical; 2010. p.175-188.

11. Oglesby AJ. Should etomidate be the induction agent of choice for rapid sequence intubation in the emergency department. Emerg Med J. 2004;21(6):655-9.

DOI: https://doi.org/10.1136/emj.2003.009043

12. Sarkar M, Laussen PC, Zurakowski D, Shukla A, Kussman B, Odegard KC. Haemodynamic responses to etomidate on induction of anaesthesia in paediatric patients. Anesth Analg. 2005;101(3):645-50.

DOI: https://doi.org/10.1213/01.ane.0000166764.99863.b4

13. Ebert TJ, Muzi M, Berens R, Goff D, Kampine JP. Sympathetic response to induction of anaesthesia in humans with propofol or etomidate. Anesthesiology. 1992;76(5):725-33

DOI: https://doi.org/10.1097/00000542-199205000-00010

14. Creagh O, Torres H, Rodríguez N, Gatica SR. Alpha-2B adrenergic receptor mediated haemodynamic profile of etomidate. P R Health Sci J. 2010;29(2):91-5.

PMID: 20496522

15. Shah SB, Chowdhury I, Bhargava AK, Sabbharwal B. Comparision of haemodynamic effects of intravenous etomidate versus propofol during induction and intubation using entropy guided hypnosis levels. J Anaesthesiol Clin Pharmacol. 2015;31(2):180-5.

DOI: https://doi.org/10.4103/0970-9185.155145

16. Meena K, Meena R, Nayak SS, Prakash S, Kumar A. A Comparative study of Effect of Propofol, Etomidate and Propofol Plus Etomidate Induction on Haemodynamic Response to Endotracheal Intubation. J Anesth Clin. 2016;7(5):622

DOI: https://doi.org/10.4172/2155-6148.1000622

17. Aggarwal S, Goyal VK, Chaturvedi SK, Mathur V, Baj B, Kumar A. A comparative study between propofol and etomidate in patients under general anaesthesia. Bras Anestesiol. 2016;66(3):237-41.

DOI: https://doi.org/10.1016/j.bjan.2016.02.010

18. Pandey AK, Makhija N, Chauhan S, Das S, Kiran U, Bisoi AK, et al. The Effects of Etomidate and Propofol Induction on Haemodynamic and Endocrine Response in Patients Undergoing Coronary Artery Bypass Graft Surgery on Cardiopulmonary Bypass. J Cardiovas Surg. 2012;2(3):48-53.

DOI: https://doi.org/10.4236/wjcs.2012.23011

19. Masoudifar M, Beheshtian E. Comparison of cardiovascular response to laryngoscopy and tracheal intubation after induction of anaesthesia by Propofol and Etomidate. J Res Med Sci. 2013;18(10):870-4.

PMID: 24497858

20. Ko YK, Kim YH, Park S, Chung WS, Noh C, Lee JU. Comparison of etomidate and propofol on intubating conditions and the onset time associated with cisatracurium administration. Korean J Anesthesiol. 2015;68(2): 136-40.

DOI: https://doi.org/10.4097/kjae.2015.68.2.136

21. Ye L, Xiao X, Zhu L. Comparison of Etomidate and Propofol Anesthesia in Patients Undergoing Gastrointestinal Endoscopy: A Systematic Review and Meta-Analysis. Surg Laparosc Endosc Percutan Tech. 2017;27(1):1-7. DOI: https://doi.org/10.1097/SLE.0000000000000373

22. Moller Petrun A, Kamenik M. BIS guided induction of GA in patients undergoing major abdominal surgery using popofol and etomidate. Br J Anes. 2013;110:388-96. 
DOI: https://doi.org/10.1093/bja/aes416

23. Bendel S, Ruokonen E, Polonen P, Uusaro A. Propofol causes more hypotension than etomidate in patients with severe aortic stenosis: a double-blind, randomised study comparing propofol and etomidate. Acta Anaesthesiol Scand. 2007;51(3):284-9.

DOI: https://doi.org/10.1111/j.1399-6576.2006.01206.x

24. Zed PJ, Abu-Laban RB, Harrison DW. Intubating Conditions and Haemodynamic effects of Etomidate for rapid sequence intubation in the emergency department: An observational cohort study. Academic Emergency Medicine. 2006;13(4):378-3.

DOI: https://doi.org/10.1197/j.aem.2005.11.076

25. Sokolove PE, Price DD, Okada P. The safety of etomidate for emergency rapid sequence intubation of paediatric patients. Pediatric Emergency Care. 2000;16(1):18-21.

DOI: https://doi.org/10.1097/00006565-200002000-00005

26. Skinner HJ, Biswas A, Mahajan RP. Evaluation of intubating conditions with rocuronium and either propofol or etomidate for rapid sequence induction. Anaesthesia. 1998;53(7):702-10.

DOI: https://doi.org/10.1046/j.1365-2044.1998.396-az0506.x

27. Mostofa MS, Mostofa PS. Comparison of the haemodynamic effects of etomidate versus propofol, rapid sequence intubation on non-surgical patients. J Meshhad University. 2014;4:602-8.

28. Glasses N, Rocchio M, Sylvester K, Beik N, Brown C, Szumita P. Evaluation of propofol versus etomidate during rapid sequence intubation in emergency department. Crit Care Med. 2013;41(12):213-4.

DOI: https://doi.org/10.1097/01.ccm.0000440092.14310.8b

29. Lipiner-friedman D, Sprung CL, Laterre PF, Weiss Y, Goodman SV. Adrenal function in sepsis: the retrospective Corticus cohort study. Crit Care Med. 2007;35(4):1012-18

DOI: https://doi.org/10.1097/01.CCM.0000259465.92018.6E 